\title{
THE INFLUENCE OF FINANCIAL RATIOS AND GOOD CORPORATE GOVERNANCE TOWARDS FINANCIAL DISTRESS ON ISLAMIC BANKS IN INDONESIA
}

\author{
NanditaSalatifaDiwanti ${ }^{1}$, Purwanto ${ }^{2}$ \\ Management Study Program, Faculty of Business, President University \\ Email: nanditasalatifadw@gmail.com¹, Purwanto@president.ac.id²
}

\begin{abstract}
This research aims to empirically prove the influence of debt to total assets ratio, capital adequacy ratio, total assets turnover, return on assets, and good corporate governance towards financial distress by Altman Z-Score. This research uses the population of Islamic banks published in the Financial Service Authority during the period 2013-2018, where the data is collected from official bank websites. Adopting a quantitative research and has 72 observations from 12 banks in six years. The result shows that capital adequacy ratio and return on assets have significant positive influence towards financial distress. While debt to total assets ratio has the significant negative influence to financial distress. However, total assets turnover and good corporate governance have a negative insignificant influence to Financial Distress. Simultaneously, all independent variables have a significant influence on financial distress, which is indicated by a value of $59.9 \%$.
\end{abstract}

Keywords: Islamic bank, z-score, financial ratios, good corporate governance

\begin{abstract}
Abstrak
Penelitian ini bertujuan untuk membuktikan secara empiris pengaruh rasio utang terhadap total aset, rasio kecukupan modal, total turnover aset, pengembalian aset, dan tata kelola perusahaan yang baik terhadap financial distress oleh Altman Z-Score. Penelitian ini menggunakan populasi bank syariah yang diterbitkan dalam Otoritas Jasa Keuangan selama periode 2013-2018, di mana data dikumpulkan dari situs web bank resmi. Mengadopsi penelitian kuantitatif dan memiliki 72 pengamatan dari 12 bank dalam enam tahun. Hasil penelitian menunjukkan bahwa rasio kecukupan modal dan pengembalian aset memiliki pengaruh positif signifikan terhadap financial distress. Sedangkan rasio utang terhadap total aset memiliki pengaruh negatif signifikan terhadap financial distress. Namun, total perputaran aset dan tata kelola perusahaan yang baik memiliki pengaruh negatif yang tidak signifikan terhadap Financial Distress. Secara bersamaan, semua variabel independen memiliki pengaruh signifikan terhadap kesulitan keuangan, yang ditunjukkan oleh nilai $59,9 \%$.
\end{abstract}

Kata kunci: Bank syariah, z-score, rasio keuangan, tata kelola perusahaan yang baik

\section{A. INTRODUCTION}

Islamic bank is a business entity that collects funds from the public in the form of deposits and distributes then to the public in the form of credit and/or other forms in the context of improving people's standard of living. Islamic banks are shown by the entry of Bank Muamalat Indonesia that categorized as a healthy bank or doesn't have any potential to bankrupt during the monetary crisis and growing rapidly after the crisis in 1997-1998. The conditions of the monetary crisis had no impact on 
Islamic banks because the operations were not based on interest rate but profit sharing systems.

There are 3 (three) types of Islamic banks which first is Islamic Commercial Banks where the business activities provide payment traffic services. Second, Islamic Business Unit is a work unit of a Conventional Commercial Banks head office that functions as a main office and branch office unit carrying out business activities based on sharia principles, and third is Islamic Rural Bank which in the activities does not collect public funds in the form of demand deposits.

Table 1. Number of Islamic Banks Office Network

\begin{tabular}{|l|c|c|c|c|c|c|c|}
\hline \multirow{2}{*}{\multicolumn{1}{|c|}{ Indicators }} & \multicolumn{7}{c|}{ Years } \\
\cline { 2 - 8 } & $\mathbf{2 0 1 3}$ & $\mathbf{2 0 1 4}$ & $\mathbf{2 0 1 5}$ & $\mathbf{2 0 1 6}$ & $\mathbf{2 0 1 7}$ & $\mathbf{2 0 1 8}$ & $\begin{array}{c}\text { Aug- } \\
\mathbf{2 0 1 9}\end{array}$ \\
\hline $\begin{array}{l}\text { Islamic Commercial } \\
\text { Bank }\end{array}$ & 11 & 12 & 12 & 13 & 13 & 14 & 14 \\
\hline Islamic Business Unit & 24 & 23 & 22 & 21 & 21 & 20 & 20 \\
\hline Islamic Rural Bank & 158 & 163 & 163 & 166 & 167 & 167 & 165 \\
\hline
\end{tabular}

Source: Financial Service Authority, 2019

Thenumbers of Islamic commercial banks have increase while the Islamic business units decrease because they converted to Islamic commercial banks. Meanwhile, the Islamic rural bank had experienced an increase in the number of banks until 2018, apparently in August 2019 reduced. Increasing the number of office network also increase the performance and it is shows by the assets, financing and third party funds of Islamic banks where it continuously increase. However, there is a slowing growth occurs in third party funds when 2017 recorded a growth of $19.83 \%$ but in 2016 reached $20.84 \%$.

Islamic banks are still able to record positive growth amid economic pressure. However, Islamic banks can still face another obstacle related to capital, economic conditions, regulatory strength and human resources. As a result of these conditions, raises many risks that will be faced which one of the risk is financial distress or bankruptcy risk. Bankruptcy is a condition where a company is no longer able to pay off the obligations. This condition usually does not just appear at the company, there are early indications from the company that can usually be recognized earlier if the financial statements are analyzed more carefully in a certain way (Toto, 2011).

Based on the description above, the researcher wanted to examine how the ratios of activity, profitability, leverage, capital and corporate governance towards financial distress in Islamic banks, especially Islamic banks that registered in Financial Service Authority.

\section{B. LITERATURE REVIEW}

\section{Signaling Theory}

Signal is an action taken by the company to give instructions to investors about how management views the company's prospects (Brigham \& Houston, 2011). This signal theory explains that all actions contain information, and this is due to the 
information asymmetry. The information provided as an announcement will give a signal to investors in making investment decisions (Jogiyanto, 2000). If the announcement contains a positive value, it is expected that market participants will react at the time of the announcement and can be accepted by market participants.

\section{Agency Theory}

Agency theory states that if there is a separation between the owner as the principal and the manager as the agent who runs the company, agency problems will arise because each party, both the principal and manager will always try to maximize their utility functions (Jensen \&Meckling, 1976). The agency problem is a conflict of interest inherent in any relationship where one party is expected to act in another's best interests.

\section{Islamic banks}

According to Law No. 21 of 2008, Islamic banks are banks that carry out business activities based on sharia principles, or Islamic legal principles regulated in the fatwa of the Indonesian Ulama Council such as the principles of justice and balance, benefit, universalism. System and mechanism to guaranteed the fulfillment of sharia compliance, which is an important issue in Islamic bank regulation. The business activities of Islamic banks must not contain elements of ribais illegally increase revenue, maysimeans transactions that are subject to an uncertain condition, ghararis buying and selling transactions that contain elements of fraud, haramis transactions that are prohibited is sharia, and zalimis a transaction that one party feels is treated unfairly.

\section{Financial Statement}

Financial statements are very helpful for shareholders in the decision-making process, and are very useful in seeing current conditions and serving as a tool to predict future conditions (Fahmi, 2013). The financialstatements are also two lists compiledby the accountant at the end of the period fora company. Both lists are balancesheet lists orfinancial position lists andincome lists or profitand loss lists. Inrecent times it has become customary for companies to adda third list, which is list of surpluses or a list of profits that are not shared (retained earnings).

\section{Financial Distress}

Financial distress is where the company's finances are in a state of financial distress, which means the company is in a critical condition and threatened with bankruptcy. Financial distress can occur in all companies and the causes of financial distress also vary. Lizal (2002) in Fachrudin (2008) mentioned grouped the causes of financial distress called the Basic Model of Bankruptcy or the Trinity of Financial Distress. There are 3 main reasons why a company can experience financial distress and bankrupt which are:

a) Neoclassical model, when financial distress and bankruptcy occur if the allocation of resources within the company is incorrect. Management is less able to allocate 
existing resources or assets in the company to the company's operational activities.

b) Financial model or mixing assets is right but the financial structure is wrong with liquidity constraints. This means that although the company can survive in the long run, it must also bankrupt in the short term.

c) Corporate governance model, the condition when bankruptcy has the right mix of assets and financial structures but is poorly managed. This inefficiency pushes the company to be out of the market as a consequence of the problems in corporate governance that are not solved.

\section{Altman Z-Score}

This Model was at first created in 1968 by Edward I. Altman where he used information drawn from substantial US organizations. He built up a model for anticipating the probability that an organization would go bankrupt. Altman the revised the model in 1983, which can be applied to private companies and not only manufacturing companies. After the revised model, Altman modified the model so that it could be applied to all companies, such as manufacturing, non-manufacturing, and bond issuing companies in emerging markets.

Where:

$$
Z=6.56 X_{1}+3.26 X_{2}+6.72 X_{3}
$$

$\mathrm{X}_{1}$ : WorkingCapital to TotalAssets

$\mathrm{X}_{2}$ : RetainedEarnings to TotalAssets

$\mathrm{X}_{3}$ : EarningBefore Interest and Taxes to TotalAssets

$\mathrm{X}_{4}$ : BookValue of Equity to TotalLiabilities

The Classification:

a. Z-score $>2.60$ means that it is in the "Safe" Zones which does not have financial problems

b. Z-score $1.1<Z<2.60$ means "Gray" Zones which are in a doubtful condition

c. Z-score $<1.1$ means, "Distress" of Zones which is in an unhealthy condition and has the potential to experience bankruptcy.

\section{Debt to total assets ratio}

Debt to total assets a ratio used to show how much a company is using debt to finance the number of its assets. According to $\mathrm{BI}$ regulation, the standard maximum of debt ratio is 0.8 . The higher the debt to total asset ratio shows the riskier the company is because the greater the debt used to purchase assets (Murhadi, 2013). If the ratio is low, the smaller the company is financed with debt (Kasmir, 2014).

\section{Capital adequacy ratio}

Capital adequacy ratio is a ratio of capital to risk weighted assets and under the government regulations. Bank Indonesia No. 9/13/PBI/2007 stated that capital adequacy ratio is the provision of minimum capital for banks based on broad risk assets, both assets listed in the balance sheet and administrative assets as reflected 
in obligations that are still contingent and/or commitments provided by banks for third parties or market risk. The higher capital adequacy ratio (based on $\mathrm{BI}$ regulation standard minimum of capital adequacy ratio is $8 \%$ ) means the higher the credit that can be distributed to increase bank profits which will then increase the level of profitability of the bank. Moreover, An increase in the capital adequacy ratio also shows an improvement in the health of banks which can reduce the risk of financial distress because high capital shows low credit (Kurniasari\&Ghozali, 2013).

\section{Total assets turnover}

Total assets turnover is a ratio that measures the turnover of all company assets and calculated by dividing net sales to average total assets (Brigham \& Houston, 2011). The higher total assets turnover means the more efficient use of overall assets in generating sales. The same amount of assets can increase sales volume if total assets turnover is increased, so that if the sales volume is large and the profit obtained is higher (Syamsudin, 2011). According to Kasmir (2014), the lower the total asset turnover ratio shows that the company has not been able to maximize its assets. The higher the total asset turnover ratio of a company will less the possibility to experience the financial distress (Jiming\&Weiwei, 2011).

\section{Return on assets ratio}

According to Horne \& Wachowicz (2005) Return on assets is a financial ratio that is used as an analytical tool to measure the performance of company management in obtaining overall profits. The lower return on assets ratio shows that financial performance is not good where the company is not able to optimize its assets to produce profits so that profitability decreases and the possibility of greater financial distress (Finishtya, 2019). Based on Indonesia Circular Letter No. 6/9/PBI/2004 the standard of return on assets is $1.5 \%$.

\section{Good corporate governance}

Good Corporate Governance is the structure and mechanism governing the management of the company so as to produce long-term sustainable economic value for shareholders and stakeholders. The assessment of good corporate governance is carried out with the level of self-assessment conducted by the company. Good Corporate Governance is defined as a set of rules and principles including Transparency, Accountability, Responsibility, Independence and Fairness (TARIF) governing the relationship between shareholders, company management (directors and commissioners), creditors, employees, and other stakeholders relating to rights and obligations each party. 


\section{RESEARCH METHODS}

1. Theoretical Framework

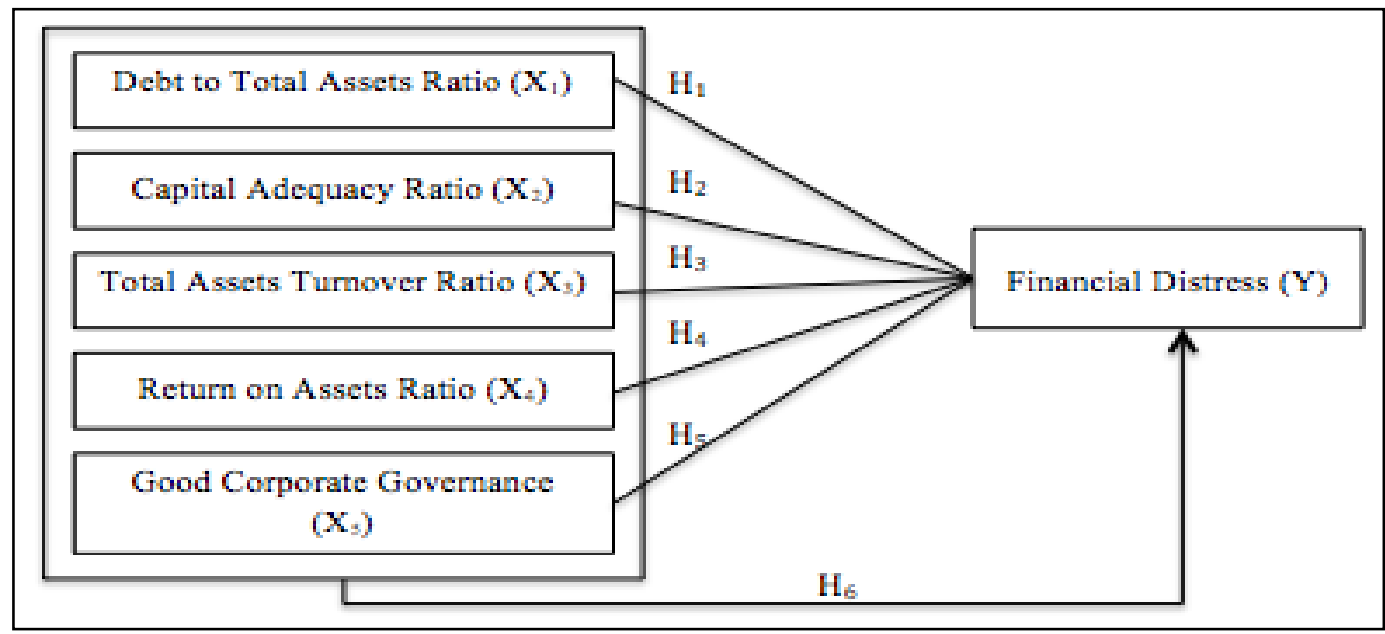

Figure 1. Theoretical Frameworks

Source: Adjusted by Researcher (2019)

\section{Hypothesis}

Based on the background description and literature review, the hypothesis can be formulated as follows:

Hypothesis 1: There is influence debt to total assets ratio towards financial distress of Islamic banks in Indonesia.

Hypothesis 2: There is influence capital adequacy ratio towards financial distress of Islamic banks in Indonesia.

Hypothesis 3: There is influence total assets turnover ratio towards financialdistress of Islamic banks in Indonesia.

Hypothesis 4: There is influence return on assets ratio towards financial distress of Islamic banks in Indonesia.

Hypothesis 5: There is influence good corporate governance towards financial distress of Islamic banks in Indonesia.

Hypothesis 6: There is simultaneous influence debt to total assets ratio, capital adequacy ratio, total assets turnover ratio, return on assets ratio, and good corporate governance toward financial distress of Islamic banks in Indonesia.

\section{Research Instrument}

The research data used secondary data. Secondary data is a source of research data obtained by researchers indirectly through intermediary media (obtained and recorded by other parties). Secondary data is generally in the form of evidence, records or historical reports that have been arranged in archives (documentary data) that are published or not published. The data used in this study were obtained from the annual financial report and GCG report of Islamic banks listing in the Financial Services Authority period 2013-2018. The data is taken from the official website of each Islamic commercial banks used in this research also from OJK at 
www.ojk.go.id. The author also uses Eviews version 10.0 and Microsoft Excel 2013 to process the data.

\section{Sample}

In this research, the selected sample is Islamic commercial banks published in the Financial Services Authority period 2013-2018 and has certain criteria that support research. According to Sugiyono (2014), the sample is a part of the number and characteristics taken by the population. The sample taken must be representative, meaning that all characteristics of the population should be reflected in the sample chosen also it has certain criteria that support research.

The criteria for choosing the sample for this research are Islamic commercial banks registered in the Financial Service Authority, Islamic commercial banks published financial report and GCG report from 2013-2018 on their official period, and Islamic commercial banks have the required data related to the variables used for research during 2013-2018. There are 72 observation data from 12 Islamic commercial banks that used in this research as sample.

\section{ANALYSIS AND INTERPRETATION}

\section{Altman Z-score}

Table 2. Z-Score Calculation Result

\begin{tabular}{|c|l|l|l|l|l|l|l|}
\hline \multirow{2}{*}{ No. } & \multicolumn{2}{|c|}{ Bank } & \multicolumn{6}{c|}{ Year } \\
\cline { 3 - 8 } & \multicolumn{2}{|c|}{$\mathbf{2 0 1 3}$} & $\mathbf{2 0 1 4}$ & $\mathbf{2 0 1 5}$ & $\mathbf{2 0 1 6}$ & $\mathbf{2 0 1 7}$ & $\mathbf{2 0 1 8}$ \\
\hline 1. & Bank Aceh Syariah & 6.67 & 6.68 & 6.62 & 7.28 & 7.43 & 8.66 \\
\hline 2. & $\begin{array}{l}\text { Bank Muamalat } \\
\text { Indonesia }\end{array}$ & 6.94 & 6.58 & 6.40 & 6.36 & 6.23 & 6.40 \\
\hline 3. & Bank Victoria Syariah & 8.02 & 6.43 & 6.34 & 7.00 & 7.89 & 7.22 \\
\hline 4. & $\begin{array}{l}\text { Bank } \\
\text { JabarBantenSyariah }\end{array}$ & 6.03 & 7.43 & 8.35 & 6.48 & 6.87 & 6.53 \\
\hline 5. & Bank BRI Syariah & 6.90 & 6.73 & 6.85 & 6.77 & 6.70 & 6.80 \\
\hline 6. & Bank BNI Syariah & 6.82 & 7.25 & 7.31 & 8.03 & 7.96 & 7.11 \\
\hline 7. & Bank BukopinSyariah & 6.24 & 6.75 & 7.00 & 7.06 & 6.54 & 6.41 \\
\hline 8. & Bank MandiriSyariah & 6.98 & 6.91 & 7.00 & 7.05 & 7.04 & 7.10 \\
\hline 9. & Bank BCA Syariah & 7.73 & 8.56 & 8.32 & 8.29 & 8.16 & 8.14 \\
\hline 10. & Bank NTB Syariah & 7.05 & 7.08 & 7.19 & 7.10 & 6.95 & 6.94 \\
\hline 11. & Bank Mega Syariah & 6.86 & 6.80 & 6.99 & 7.99 & 7.23 & 7.62 \\
\hline 12. & $\begin{array}{l}\text { Bank Panin Dubai } \\
\text { Syariah }\end{array}$ & 7.92 & 7.91 & 8.03 & 7.76 & 5.56 & 7.76 \\
\hline
\end{tabular}

Source: Adjusted by Research, 2019

There are no Islamic commercial banks that are classified as distress or are stated to have experienced financial distress where there are no banks that have a value of $<1.1$ So that they are declared experiencing financial distress where the company is experiencing financial distress and potentially bankruptcy. In addition, the Islamic commercial banks above is also not in the gray zone or has a value $<2.6$ so it can be 
said that the Islamic bank used in this research is not in a bankruptcy-prone condition.

\section{Descriptive Analysis}

There are five independent variables used in this research which are debt to total assets ratio, capital adequacy ratio, total assets turnover, return on assets, and good corporate governance. The dependent variable in this research is financial distress (Altman Z-Score). There are 72 units of observation for 6 years period (2013-2018).

Table 3. Descriptive Statistic Result

\begin{tabular}{|l|c|c|c|c|c|c|}
\hline & DAR & CAR & TATO & ROA & GCG & FD \\
\hline Mean & 0.28653 & $\begin{array}{c}19.2286 \\
1\end{array}$ & $\begin{array}{c}11.0130 \\
6\end{array}$ & 0.90125 & 1.88597 & 7.16792 \\
\hline Maximum & 0.93 & 36.70 & 27.09 & 5.10 & 3.00 & 9.32 \\
\hline Minimum & 0.08 & 11.10 & 4.45 & -10.77 & 1.00 & 5.56 \\
\hline Std. Dev. & 0.27723 & 5.81473 & 3.50668 & 1.93451 & 0.58965 & 0.71979 \\
& 1 & 8 & & 8 & 9 & 4 \\
\hline Observations & 72 & 72 & 72 & 72 & 72 & 72 \\
\hline
\end{tabular}

Source: Eviews 10, 2019

\section{Hausman Test}

Table 4. Hausman Test Result

\begin{tabular}{|lrrr|}
\hline $\begin{array}{l}\text { Correlated Random Effects - Hausman Test } \\
\text { Equation: Untitled } \\
\text { Test cross-section random effects } \\
\end{array}$ Chi-Sq. Statistic & Chi-Sq. d.f. & Prob. \\
\hline \hline Test Summary & 8.849970 & 5 & 0.1152 \\
\hline \hline Cross-section random & & & \\
\hline
\end{tabular}

Source: Eviews 10, 2019

Hausman test results in this research shows that the value of Prob. $>$ Chi-Sq of 0.1152 whose value is greater than 0.05 so that $\mathrm{Ho}$ is accepted. This means that in this research the estimation model that is more appropriate to use is the Random Effect rather than Fixed Effect. Based on the results of the Chow test and the Hausman test, the most appropriate method used in this research model is the Random Effect method. 


\section{Classical Assumption Test}

\subsection{Normality Test}

\section{Table 5. Normality Test Result}

Source: Eviews 10, 2019

\begin{tabular}{|c|c|}
\hline \multicolumn{2}{|c|}{$\begin{array}{l}\text { Series: Residuals } \\
\text { Sample } 172 \\
\text { Observations } 72\end{array}$} \\
\hline mean & $-9.73 e-16$ \\
\hline Median & -0.040217 \\
\hline Maximum & 1.225287 \\
\hline Minirnumn & -1.004933 \\
\hline Std. Dev. & 0.439225 \\
\hline Skemness & 0.305714 \\
\hline Kurtosis & 3.022625 \\
\hline Jarque-Eera & 1.123070 \\
\hline Probability & 0.5703330 \\
\hline
\end{tabular}

Based on the table above, it shows the histogram with the value of Jarque-Bera is 1.123070 and the probability is $0.570333>0.05$, which means the distribution of the regression model is normal.

\subsection{Multicollinearity Test}

Table 6. Multicollinearity Coefficient Correlations Test Result

\begin{tabular}{|l|c|c|c|c|c|}
\hline & $\begin{array}{c}\text { Debt to } \\
\text { Total } \\
\text { Assets } \\
\text { Ratio }\end{array}$ & $\begin{array}{c}\text { Capital } \\
\text { Adequacy } \\
\text { Ratio }\end{array}$ & $\begin{array}{c}\text { Total } \\
\text { Assets } \\
\text { Ratio }\end{array}$ & $\begin{array}{c}\text { Return on } \\
\text { Assets }\end{array}$ & $\begin{array}{c}\text { Good } \\
\text { Corporate } \\
\text { Governanc } \\
\text { e }\end{array}$ \\
\hline $\begin{array}{l}\text { Debt to Total } \\
\text { Assets Ratio }\end{array}$ & 1.000000 & 0.115965 & 0.079964 & 0.335122 & 0.129720 \\
\hline $\begin{array}{l}\text { Capital } \\
\text { Adequacy Ratio }\end{array}$ & 0.115965 & 1.000000 & -0.061935 & 0.332662 & -0.300346 \\
\hline $\begin{array}{l}\text { Total Assets } \\
\text { Turnover }\end{array}$ & 0.079964 & -0.061935 & 1.000000 & 0.199954 & 0.018510 \\
\hline $\begin{array}{l}\text { Return on } \\
\text { Assets }\end{array}$ & 0.335122 & 0.332662 & 0.199954 & 1.000000 & -0.114042 \\
\hline $\begin{array}{l}\text { Good Corporate } \\
\text { Governance }\end{array}$ & 0.129720 & -0.300346 & 0.018510 & 0.114042 & 1.000000 \\
\hline
\end{tabular}

Source: Eviews 10, 2019

The table shows the correlation value between independent variables is smaller than $0.8(<0.8)$, which means the model does not contain multicollinearity problems or the assumption that multicollinearity does not occur in the model are met. Moreover, to determine the presence or absence of multicollinearity also can be looking at the value of VIF. If the VIF value is less than 10 then it is stated that there is no multicollinearity(Ghozali, 2011). 
Table 7.Multicollinearity VIF Test Result

\begin{tabular}{|c|c|c|c|}
\hline \multicolumn{4}{|c|}{$\begin{array}{l}\text { Variance Inflation Factors } \\
\text { Date: } 11 / 01 / 19 \text { Time: } 15: 17 \\
\text { Sample: } 172 \\
\text { Included observations: } 72\end{array}$} \\
\hline Variable & $\begin{array}{c}\text { Coefficient } \\
\text { Variance }\end{array}$ & $\begin{array}{c}\text { Uncentered } \\
\text { VIF }\end{array}$ & $\begin{array}{c}\text { Centered } \\
\text { VIF }\end{array}$ \\
\hline $\mathrm{C}$ & 0.130116 & 45.14131 & $N A$ \\
\hline DAR & 0.044430 & 2.433709 & 1.168232 \\
\hline CAR & 0.000108 & 15.06890 & 1.246452 \\
\hline TATO & 0.000253 & 11.68891 & 1.062410 \\
\hline $\mathrm{ROA}$ & 0.001031 & 1.610049 & 1.319605 \\
\hline $\mathrm{GCG}$ & 0.009583 & 12.96480 & 1.139871 \\
\hline
\end{tabular}

Source: Eviews 10, 2019

Based on table 7, it can be seen that there is no multicollinearity problem. This can be seen from the value of centered VIF for the five independent variables less than 10. The value of centered VIF forDAR is $1.168232<10$, CAR is $1.246452<10$, TATO is $1.062410<10$, ROA is $1.319605<10$, and GCG is $1.139871<10$.

\subsection{Autocorrelation Test}

Table 8. Durbin-Watson Test Result

\begin{tabular}{|l|c|}
\hline \multicolumn{2}{|c|}{ Weighted Statistics } \\
\hline Durbin-Watson stat & 1.276035 \\
\hline
\end{tabular}

The result of Durbin-Watson test above shows the regression model no autocorrelation problem because the Durbin-Watson test is 1.276035 or it is more than -2 but less than +2 .

\subsection{Heteroscedasticity Test}

Table 9. Breusch-Pegan Test Result

\begin{tabular}{|llll|}
\hline \multicolumn{3}{l}{ Heteroskedasticity Test: Breusch-Pagan-Godfrey } \\
Null hypothesis: Homoskedasticity & & \\
\hline \hline F-statistic & 2.382976 & Prob. F(5,66) & 0.0476 \\
Obs*R-squared & 11.01036 & Prob. Chi-Square(5) & 0.0512 \\
Scaled explained SS & 9.356425 & Prob. Chi-Square(5) & 0.0957 \\
\hline
\end{tabular}

Source: Eviews 10, 2019

According to the table 9 where the $p$ value is indicated by the Prob. chi square in Obs ${ }^{*} \mathrm{R}$-Squared that is equal to $0.0512>0.05$, then accept Ho or that means the regression model is homoscedasticity or in other words there is no problem of assumption of non-heteroscedasticity. 


\section{Multiple Regression Model Result}

Table 10. Multiple Regression Analysis Result

\begin{tabular}{|crrrr|}
\hline $\begin{array}{l}\text { Dependent Variable: FD } \\
\text { Method: Least Squares } \\
\text { Date: } 11 \text { 101/19 Time: } 15: 16 \\
\text { Sample: } 172\end{array}$ & & & \\
Included observations: 72 & & & & \\
\hline \hline Variable & Coefficient & Std. Error & t-Statistic & Prob. \\
\hline \hline C & 6.393563 & 0.360716 & 17.72464 & 0.0000 \\
DAR & -1.370744 & 0.210785 & -6.503058 & 0.0000 \\
CAR & 0.065395 & 0.010381 & 6.299746 & 0.0000 \\
TATO & -0.000125 & 0.015892 & -0.007852 & 0.9938 \\
ROA & 0.109204 & 0.032104 & 3.401527 & 0.0011 \\
GCG & -0.099363 & 0.097891 & -1.015036 & 0.3138 \\
\hline
\end{tabular}

Source: Eviews 10, 2019

According to table 10, the multiple regression analysis is interpreted in the standardized equation as below:

Financial Distress = 6.393563 -1.370744 DAR + 0.065395 CAR -0.000125

TATO + 0.109204 ROA - 0.099363 GCG

\section{Testing Hypothesis}

\subsection{T-Test}

$T$ test is used to determine whether partially the independent variable significantly influences the dependent variable. Based on the table 4.9, the hypothesis of T-Test result that are accepted as follow:

a) Debt to total assets ratio obtained t-statistic of -6.50306 with a probability of $0,000<0.05$. It means that $\mathrm{Ha}$ is accepted and $\mathrm{Ho}$ is rejected. Thus, hypothesis 1 is accepted.

b) Capital adequacy ratio obtained t-statistic of 6.29975 with a probability of 0,000 $<0.05$. It means that $\mathrm{Ha}$ is accepted and $\mathrm{Ho}$ is rejected. Thus, hypothesis 2 is accepted.

c) Total assets turnover obtained t-statistic of -0.00785 with a probability of 0,994 $>0.05$. It means that $\mathrm{Ha}$ is rejected and $\mathrm{Ho}$ is accepted. Thus, hypothesis 3 is rejected.

d) Return on assets ratio obtained t-statistic of 3.40153 with a probability of 0,001 $<0.05$. It means that $\mathrm{Ha}$ is accepted and $\mathrm{Ho}$ is rejected. Thus, hypothesis 4 is accepted.

e) Good corporate governance obtained t-statistic of -1.01504 with a probability of $0,314>0.05$. It means that $\mathrm{Ha}$ is rejected and $\mathrm{Ho}$ is accepted. Thus, hypothesis 5 is rejected. 


\subsection{F-Test}

The $\mathrm{F}$ test basically shows whether all independent variables entered in the model have a joint influence on the dependent variable.

Table 11. F-Test Result

\begin{tabular}{|l|c|}
\hline \multicolumn{2}{|c|}{ Weighted Statistics } \\
\hline F-Statistic & 22.24999 \\
\hline Prob (F-statistic) & 0.00000 \\
\hline
\end{tabular}

Source: Eviews 10, 2019

F-statistic is 22.24999 with a probability of $0,000<0.05$ which means $\mathrm{Ha}$ is accepted and $\mathrm{Ho}$ is rejected. This shows that all independent variables Debt to total assets ratio, Capital adequacy ratio, Total assets turnover, Return on assets, and Good corporate governance have a significant simultaneous effect towards Financial distress and regression models can be used.

\subsection{Coefficient of Determination $\left(\mathbf{R}^{2}\right)$}

Table 12. Coefficient of Determination Result

\begin{tabular}{|c|c|c|}
\hline Standard Value & Result & Category \\
\hline $0-3.99 \%$ & & Very Weak \\
\hline $4-15.99 \%$ & & Weak \\
\hline $16-35.99 \%$ & & Average \\
\hline $36-63.99 \%$ & $59.9436 \%$ & Strong \\
\hline $64-100 \%$ & & Very Strong \\
\hline
\end{tabular}

Source: Sugiyono (2012) and adjusted by researcher, 2019

Based on the results of the determination test in table 12, the coefficient of determination value or Adjusted $R^{2}$ is 0.599 , this means that $59.9 \%$ of financial distress variation can be explained by variations of the five variables that affect financial distress. While the rest $(100 \%-59.9 \%=40.1 \%)$ is explained by other variables not included in the above mentioned equation model.

\section{Interpretation of Results}

\section{a. Influence of Debt to Total Assets ratio towards Financial distress}

The first hypothesis states that there is significant influence of debt to total assets ratio towards financial distress. Significant value of 0.000 the hypothesis is accepted with the coefficient regression of -1.370744 . Debt to total assets ratio has negative influence towards financial distress which measured by Z-score as proxy, means that an increase in debt to total assets ratio will consequence a decreasing on Z-score and leads to increase in financial distress.

According to agency theory, the survival of the company is in the hands of agents, including deciding whether to make funding from third parties or not. The agent uses too many third party funds as a fund, then there will be a greater obligation in the future, and it will causing the company to be vulnerable to financial distress. The 
higher debt to total assets ratio indicates a high risk because there is a concern that the company will not be able to cover its debts with its assets so that it will be more difficult to obtain additional loans (Murhadi, 2013). The results of this research are consistent with the results of Alifiah (2014) which found that the debt to total assets ratio had a negative and significant effect on financial distress.

\section{b. Influence of Capital Adequacy Ratio towards Financial distress}

The second hypothesis states that there is significant influence of capital adequacy ratio towards financial distress.Significant value of 0.000 the hypothesis is accepted with the coefficient regression of 0.065395 . Capital adequacy ratio has positive influence towards financial distress which measured by Z-score as proxy, means that an increase capital adequacy ratio will consequence an increasing on Z-score and leads to decrease in financial distress.

According to Kurniasari \& Ghozali (2013) mentioned that banks that has a high capital adequacy ratio indicates an improvement in bank health, so that it will reduce the risk of financial distress. Banks that have high capital adequacy ratio will be willing to lend their funds in the expectation that they will get a large profit. Research conducted by Suhadi \& Kusumaningtias (2017) also shows the same results where the capital adequacy ratio has a positive effect on financial distress.

\section{c. Influence of Total Assets Turnover towards Financial distress}

The third hypothesis states that there is no significant influence of total assets turnover towards financial distress. Significant value of 0.994 the hypothesis is rejected with the coefficient regression of -0.000125 . Total assets turnover has negative influence towards financial distress which measured by Z-score as proxy, means that an increase in total assets turnover will consequence a decreasing on $Z$ score and leads to increase in financial distress.

High total assets turnover shows the company's effectiveness in the use of its assets (Kasmir, 2014). According to signal theory that is an action taken by company to give clues for investors about how management views the prospects of the company. Information issued by the company is important, because the effect on investment decisions outside the company (Brigham and Houston 2011). This research is consistent with research conducted by Priyatnasari\& Hartono (2019), which show total assets turnover has no significant influence and cannot predict financial distress. As the opposite, research done by Alifiah (2014) found that there is positive and significant relationship between total assets turnover and financial distress.

\section{d. Influence of Return On Assets towards Financial distress}

The forth hypothesis states that there is significant influence return on assets towards financial distress. Significant value of 0.001 the hypothesis is accepted with the coefficient regression of 0.109204 . Return on assets has positive influence towards financial distress which measured by Z-score as proxy, means that an increase return on assets will consequence an increasing on Z-score and leads to decrease in financial distress. 
The result in line with previous research by Amalia\&Mardani (2017) and consistent to signal theory, where the higher return on assets will give a good signal to investors that the company can provide good prospects because it has the ability to generate profits by managing its assets effectively. Conversely, research conducted by Theodorus\&Artini (2018) and Priyatnasari\& Hartono (2019) that indicate the return on assets ratio has negative and significant influence to predict financial distress conditions.

\section{e. Influence of Good Corporate Governance towards Financial distress}

The fifth hypothesis states that there is no significant influence good corporate governance towards financial distress. Significant value of 0.314 the hypothesis is accepted with the coefficient regression of -0.0 .99363 . Good corporate governance has negative influence towards financial distress which measured by Z-score as proxy, means that an increase in good corporate governance will consequence a decreasing on Z-score and leads to increase in financial distress.

In Bank Indonesia Circular No. 13/1/PBI/2011 stated that the smaller the composite value reflects the better application of good corporate governance. . This means that with a small composite value Islamic banks have met the standards set by Bank Indonesia. However, the result shows that good corporate governance had no significance influence on financial distress. This is in line with the previous research by supported by Qoriah \& Nurdin (2013) but inconsistent to agency theory where states that good corporate governance can reduce agency problems between the owner and manager so that the alignment of interests between the company owner and manager arises. So it does not create a management agency cost that can cause a company's financial distress.

\section{f. Debt to Total Assets, Capital Adequacy Ratio, Total Assets Turnover, Return on Assets, Good Corporate Governance has simultaneous significant effect towards Financial Distress of Islamic Banks in Indonesia}

The f-statistic coefficient determination in this hypothesis is $0.000(<0.05)$. Therefore the hypothesis is accepted. Based in the analysis, the independent variables are able to influence the financial distress by $59.9 \%$, while other influences the remaining of $40.1 \%$ variables that are not include in this research.

\section{g.The Most Significant Influence Factors towards Financial Distress}

Debt to total assets ratio becomes independent variable with the most significant effect with a coefficient 1.370744 , followed by return on assets with a coefficient of 0.109204 . In the third place where found not significant, good corporate governance with coefficient value of 0.099363 while the forth place for capital adequacy ratio with coefficient of 0.065395 . The last but not least, total assets turnover with coefficient of 0.000125 which also found not significant in this research. 


\section{E. CONCLUSION AND RECOMMENDATION}

\section{Conclusion}

a. Islamic banks used as sample in this research on the safe zones in the calculation of Altman Z-score.

b. Debt to total assets ratio has negative and significant influence towards financial distress of Islamic banks. The large amount of debt indicates that the company is in bad condition because the cost used for the company is increasing which resulting in potential financial distress. Debt to total assets ratio measured how extreme the company uses its own debt to operate.

c. Capital adequacy ratio has positive and significant influence towards financial distress of Islamic banks. Higher capital adequacy ratio shows the Islamic banks has better operational activities where able stay from risk of loss and reduce the risk of financial distress.

d. Total assets turnover has negative and not significant influence towards financial distress of Islamic banks.

e. Return on assets has positive and significant influence towards financial distress of Islamic banks. The greater return on assets leads the effective Islamic banks and it gives the positive sign for investor to invest.

f. Good corporate governance has negative and not significant influence towards financial distress of Islamic banks.

g. Debt to total assets, capital adequacy ratio, total assets turnover, return on assets, good corporate governance could explain the about the variance of financial distress $59.9 \%$.

$\mathrm{h}$. Debt to total assets becomes independent variable with the most significant effect and followed by return on assets, good corporate governance, capital adequacy ratio, and total assets turnover.

\section{Recommendation}

\section{a. Islamic banks}

Islamic banks especially for Islamic commercial banks must maintain and pay attention to financial statements to avoid bankruptcy and financial distress. In terms of financial ratios measurements like debt to total assets, capital adequacy ratio and return on assets ratios which have been determined to have a significant influence on predicting financial distress. Hence, the Islamic banks must improve its performance thus the result from the ratios shows good result condition.

\section{b. Investors}

Investors can make the results of the analysis as investment considerations and can make decisions as a comparison in predicting financial distress. Investors have the ability to avoid losses as a form of risk management. Banks allow being stronger than before if supported by investors who can see the potential and desire to help the banking industry. 


\section{c. Future Researchers}

Further researchers are expected to be able to replace or add another variable size used in describing the financial distress condition of banks, and can develop research samples not only on Islamic commercial bank but also Islamic rural banks and Islamic business unit, so it can be generalized or statistically increase the percentage of testing strength, and extend the observation period.

\section{REFERENCES}

Alifiah, M. N. (2014). Prediction of Financial Distress Companies in the Trading and Services Sector in Malaysia Using Macroeconomic Variables. Procedia - Social and Behavioral Sciences, 129, 90-98.

Altman, E. I. (2000). Predicting Financial Distress of Companies: Revisiting The ZScore and ZETA Models. The Federal Lands Revisited, 1(July), 1-302.

Amalia, N. I., \& Mardani, R. M. (2017). Analisis Rasio Keuangan Terhadap Financial Distress (Pada Perusahaan Perbankan Yang Listing Di BEl Periode Tahun 2014-2016). E-Journal Riset Manajemen.

Brigham, E. F., \& Houston, J. F. (2011). Dasar-Dasar Manajemen Keuangan. In Salemba Empat (11th ed.).

Fahmi, I. (2013). Analisa Laporang Keuangan. In Bandung : Alfabeta.

Fachrudin, K. A. (2008). Kesulitan Keuangan Perusahaan dan Personal. USU Press.

Finishtya, F. C. (2019). the Role of Cash Flow of Operational , Profitability , and Financial Leverage in Predicting Financial Distress on Manufacturing Company in Indonesia. Universitas Ciputra Surabaya, 17(1).

Ghozali. (2011). Aplikasi Analisis Multivariate dengan Program SPSS. Jurnal IImiah Universitas Pandanaran.

Horne, J. C., \& Wachowicz, J. M. (2005). Prinsip-Prinsip Manajemen Keuangan. In Fundamental of Financial Management (12th ed.).

Jensen, Michael C. \& W.H. Meckling. (1976). Theory of The Firm: Managerial Behavior, Agency Cost and Ownership Structure. Journal of Financial Economics 3. 305-360.

Jiming, L., \& Weiwei, D. (2011). An empirical study on the corporate financial distress prediction based on logistic model: Evidence from China's manufacturing Industry. International Journal of Digital Content Technology and Its Applications, 5(6), 368-379.

Jogiyanto, H. (2000). Teori Portofolio and Analisis Investasi (2nd ed.). Yogyakarta: BPFE UGM.

Kasmir. (2014). Analisis Laporan Keuangan. In PT. Raja Grafindo Persada Jakarta. 
Kurniasari, C., \& Ghozali, I. (2013). Analisis Pengaruh Rasio Camel Dalam Memprediksi Financial Distress Perbankan Indonesia. 2, 98-107.

Murhadi, W. R. (2013). Analisis Laporan Keuangan Proyeksi dan Valuasi Saham. In Salemba Empat.

Priyatnasari, S., \& Hartono, U. (2019). Rasio Keuangan, Makroekonomi dan Financial Distress: Studi pada Perusahaan Perdagangan, Jasa dan Investasi di Indonesia. Journal IImu Manajemen, 7(4).

Qoriah, N., \& Nurdin. (2018). Analisis Model Rgec (Risk Profile, Good Corporate Governance, Earnings, And Capital) dalam Mengetahui Potensi Financial Distress pada Bank Umum Syariah Periode 2012-2017. Prosiding Manajemen.

Sugiyono. (2014). Metode Penelitian Kuatintatif, Kualitatif dan R\&D. In Alfabeta.

Suhadi, A., \& Kusumaningtias, R. (2017). Pengaruh Rasio Keuangan Terhadap Kondisi Financial Distress Bank Umum Syariah di Indonesia. Universitas Negeri Surabaya, 1(4), 53.

Syamsudin, L. (2011). Manajemen Keuangan Perusahaan. Jakarta: RajaGrafindo.

Theodorus, S., \& Artini, L. G. S. (2018). Studi Financial Distress pada Perusahaan Perbankan di BEl. E-Jurnal Manajemen Unud, 7(5), 2710-2732.

Toto, P. (2011). Analisis Laporan Keuangan Teori dan Aplikasi. Jakarta: PPM. 